\title{
Which end: dissecting Ku's function at telomeres and double-strand breaks
}

\author{
Alison A. Bertuch ${ }^{1,2,3}$ and Victoria Lundblad ${ }^{1}$ \\ ${ }^{1}$ Department of Molecular and Human Genetics and ${ }^{2}$ Department of Pediatrics, Hematology/Oncology Section, Baylor \\ College of Medicine, Houston, Texas 77030, USA
}

The ends of chromosomes are active places. These natural DNA termini must be protected from degradation, recombination, and end-to-end fusions-events that would be ultimately fatal for the genome. In addition, the enzyme telomerase ensures that telomeres in proliferating cells, such as single-celled organisms like budding yeast or the mammalian germ line, are completely replicated. Over the past decade, a plethora of telomereassociated proteins have been identified, based on their ability to regulate telomerase access, provide protection from nucleases and recombinases, and control telomere length (for review, see McEachern et al. 2000; de Lange 2002). In the budding yeast, at least a dozen proteins interact with just the terminal single-stranded overhang, with an additional dozen or more proteins that are associated with the duplex region of the telomere. At mammalian telomeres, which are bound by additional factors that are apparently not present in yeast, the situation is even more complex.

To make the task of understanding events that take place at telomeres even more challenging, many telomere-associated proteins perform more than one biochemical activity at chromosome ends. For example, in human cells, the telomere repeat binding factor TRF2 protects chromosomes from end-to-end fusions, and also acts as a negative regulator of telomere length (van Steensel et al. 1998; Loayza and De Lange 2003). The yeast telomere end-binding factor Cdc13 similarly performs several discrete tasks: Cdc13 both positively and negatively regulates telomere elongation by telomerase, as well as shields chromosome termini from unregulated degradation by nucleases (Garvik et al. 1995; Nugent et al. 1996; Booth et al. 2001; Chandra et al. 2001). Analyses of these Cdc13-mediated processes have been greatly aided by separation-of-function mutations that appear to selectively impair each activity. In an analogous manner, recent genetic studies of the catalytic subunit of telomerase have helped to identify discrete regions that mediate enzyme processivity, interaction with other telomerase subunits, or recruitment of the telomerase com-

${ }^{3}$ Corresponding author.

E-MAIL abertuch@bcm.tmc.edu; FAX (713) 798-3457.

Article and publication are at http://www.genesdev.org/cgi/doi/10.1101/ gad.1146603. plex to chromosome termini (Peng et al. 2001; Armbruster et al. 2003; Friedman et al. 2003; Kim et al. 2003).

One factor that is critical to several aspects of telomere biology, yet has lagged behind in this genetic dissection, is the $\mathrm{Ku}$ heterodimer. Composed of 70- and $80-\mathrm{kD}$ subunits, $\mathrm{Ku}$ was first appreciated for its role in double-strand break (DSB) repair (Taccioli et al. 1994). In both mammalian and yeast cells, DSBs that arise via developmentally regulated site-specific rearrangements [e.g., V(D)J recombination in vertebrate cells], or are induced experimentally or as a result of environmental assaults such as irradiation, must be readily repaired to maintain genome stability. Ku plays a central role in this process by binding to DNA double-strand ends and recruiting additional factors, which are required to complete repair via nonhomologous end-joining (for review, see Jackson 2002).

Somewhat paradoxically, $\mathrm{Ku}$ also functions at telomeres, even though these DNA termini are not normally substrates for end-joining reactions. In fact, telomeres must be specifically protected from end-to-end fusions to maintain genomic stability. Furthermore, the role that the $\mathrm{Ku}$ heterodimer plays at telomeres is complex, as evidenced by the fact yku70- $\Delta$ or yku80- $\Delta$ budding yeast strains, although still viable, exhibit an impressively large number of phenotypes, indicative of severe telomere dysfunction. In these Ku-defective strains, the structure of the extreme single-stranded termini is altered by increased exposure to nucleolytic activity (Gravel et al. 1998; Polotnianka et al. 1998; Maringele and Lydall 2002). Yeast strains that lack Ku also have substantially shortened telomeres (Boulton and Jackson 1996; Porter et al. 1996), in part because of this enhanced nuclease action (A.A. Bertuch and V. Lundblad, in prep.), but primarily because of impaired regulation of telomerase (Peterson et al. 2001; Stellwagen et al. 2003). Additionally, loss of $\mathrm{Ku}$ function in yeast disrupts the transcriptional silencing of telomere-proximal genes, by altering the composition of factors that comprise telomeric heterochromatin (Laroche et al. 1998; Nugent et al. 1998; Mishra and Shore 1999).

Analysis of $y k u 70-\Delta$ or $y k u 80-\Delta$ yeast null strains, therefore, has firmly established that the Ku heterodimer is a multifunctional player that contributes to telomere 
length regulation and end protection, and even duplex telomeric chromatin structure. However, insight into how this collection of telomere-related activities is performed, and how $\mathrm{Ku}^{\prime}$ s function at telomeres can be differentiated from that at double-strand breaks, has been impossible to ascertain from analysis of the null phenotype. As a result, models for how Ku performs each of its activities - and even evidence that each of these roles are the result of discrete biochemical activities-have been lacking.

In this issue of Genes \& Development, Gottschling and colleagues (Stellwagen et al. 2003) define Ku's role in telomere length regulation, by demonstrating that $\mathrm{Ku}$ specifically interacts with the yeast telomerase RNA to facilitate telomerase action at telomeres. Previous work by this same group had identified a 48-nt region of the yeast telomerase RNA, TLC1, that is required for some aspect of telomere length regulation: a strain carrying the t1c1- $\Delta 48$ mutation, deleted for this region of TLC1, displays short telomeres (Peterson et al. 2001). This region of the TLC1 RNA forms into a stem-loop structure, with features suggesting that it might provide a site(s) for protein binding. In fact, increased expression of this stem-loop in an otherwise wild-type yeast strain disrupts telomeric silencing, implying that the overexpressed stem-loop is titrating a factor-such as $\mathrm{Ku}-$ away from telomeric chromatin.

Stellwagen et al. (2003) have now established that $\mathrm{Ku}$ is, in fact, the culprit, by showing that purified yeast $\mathrm{Ku}$ heterodimer binds the 48-nt TLC1 stem-loop, but not a mutated version of this RNA structure. As a reciprocal test, they used a clever genetic screen to isolate a mutant version of the $\mathrm{Ku}$ heterodimer (with the Ku80 subunit encoded by this new allele, called yku80-135i) that has lost its ability to bind this TLC1 structure. Like a t1c1$\Delta 48$ strain, the yku80-135i mutant strain also exhibits short telomeres, and an assessment of de novo telomere formation at a newly exposed DNA end showed that the kinetics and extent of the telomere addition reaction are reduced. However, only the telomere elongation function of $\mathrm{Ku}$ is impaired, as chromosome end protection is still intact in the yku80-135i mutant strain. These observations have elegantly and decisively defined one activity of the Ku heterodimer: it promotes telomere elongation by telomerase, through an interaction between the Yku80 subunit and the telomerase RNA. Whether this interaction between $\mathrm{Ku}$ and telomerase mediates recruitment of the enzyme to chromosome ends, or instead facilitates telomerase action once it has arrived at the telomere, awaits further analysis.

Gottschling's group (Stellwagen et al. 2003) also examined the behavior of telomerase at DSBs in the yku80135i strain, and this second part of their analysis further illustrates how informative a separation-of-function mutation can be. Just as telomeres are resistant to the activities that normally ligate DSBs, newly broken ends are not efficient substrates for telomerase. In fact, there appears to be an active mechanism to prevent telomerasemediated healing of broken chromosomes (Kolodner et al. 2002). However, at very low frequencies, telomerase will nevertheless form telomeres de novo at spontaneously created DNA breaks. Using a genetic system devised by Kolodner and colleagues that allows the recovery of strains that have repaired spontaneous chromosome breakage (Myung et al. 2001), Stellwagon et al. (2003) showed that the ability to heal DNA damage by telomerase is reduced many-fold in the yku80-135i strain. However, their analysis uncovered an intriguing twist. Careful inspection of the sites of telomerase addition revealed that in a wild-type strain, healing at spontaneous breaks often takes place at naturally occurring G-rich seed sequences that resemble the G-rich repeats found at telomeres. This suggests that the sequence-specific telomere end-binding protein $\mathrm{Cdc} 13$, which is responsible for recruiting telomerase to chromosome ends (Evans and Lundblad 1999; Pennock et al. 2001), may similarly mediate the access of telomerase to doublestrand breaks (albeit at extremely low frequencies). Curiously, however, de novo telomere addition can also occur at completely random sequence sites in a wild-type strain. The spectrum of chromosome healing events that occurred in the yku80-135i strain provides a potential explanation: in this mutant background, telomere addition events exhibit a strong bias for sites that contain G-rich tracts, with essentially no healing at sites that lack a G-rich seed. Thus, one possible explanation for this dichotomy is that $\mathrm{Cdc} 13$ preferentially recruits telomerase to one set of sites, whereas Ku can promote sequence-independent telomerase access. Alternatively, $\mathrm{Ku}$ 's role in this process may occur subsequent to the arrival of telomerase at a break, perhaps by stabilizing base-pairing between the substrate and the TLC1 template.

Thus, $\mathrm{Ku}$ appears to be capable of performing a common function at both natural chromosome termini and those created by DSBs, by facilitating the telomere addition reaction. However, a key feature that distinguishes these two types of termini is their susceptibility to DNA joining. Whereas $\mathrm{Ku}$ promotes rejoining of DSBs, it is inhibited from doing the same at telomeres. This has led to the question of whether the end-joining activity that $\mathrm{Ku}$ plays at DSBs is separable from the multiple activities that $\mathrm{Ku}$ contributes to telomere function. The answer appears to be yes. Although the yku80-135i mutant strain is defective in telomere length regulation, it fully retains the ability to participate in DSB repair. Further support for separable functions comes from an additional set of seven alleles of YKU80, referred to as yku80 tel alleles, which were recovered from different separationof-function genetic screens (Bertuch and Lundblad 2003). Strains bearing these $y \mathrm{ku} 80^{\text {tel }}$ missense mutations have lost the ability to protect telomere ends from aberrant nucleolytic degradation, but are still competent to repair broken ends.

Once restricted by null phenotypes, characterization of these new alleles has initiated the genetic dissection of the different biochemical activities of Ku. Further insight has been gained by placing these separation-offunction mutations onto the crystal structure of human $\mathrm{Ku}$ bound to DNA. The human Ku heterodimer forms a 


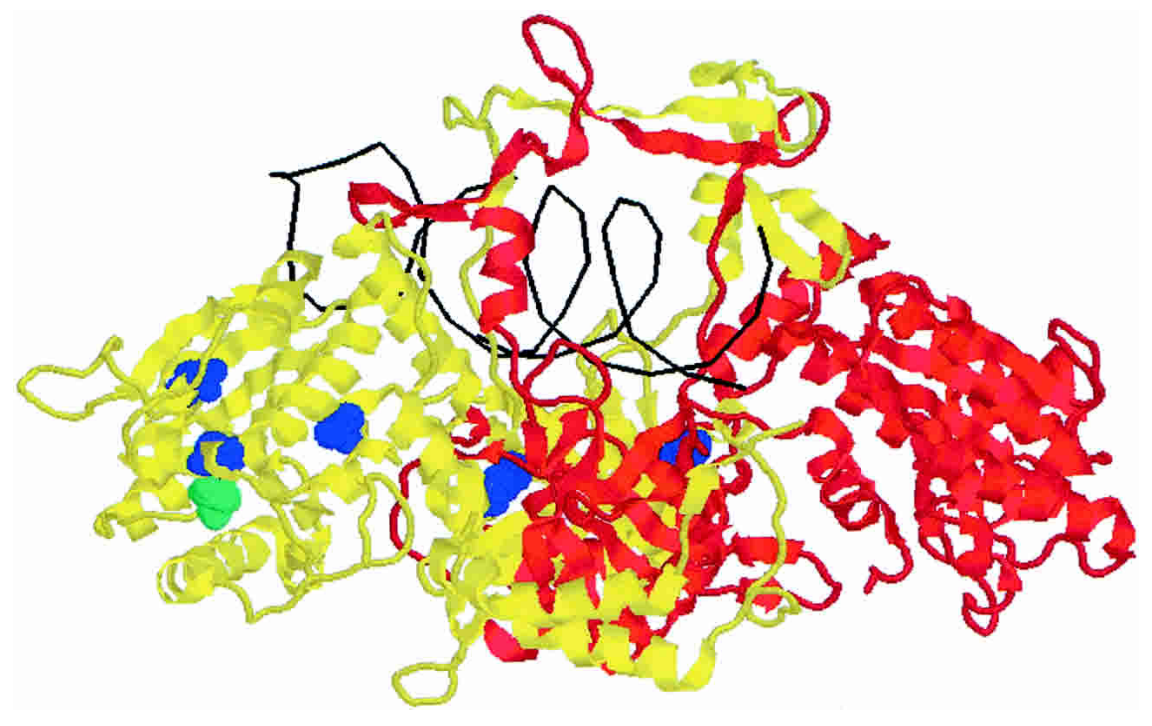

Figure 1. Ku80 separation-of-function mutants map predominately to the $\mathrm{Ku} 80 \mathrm{~N}$ terminal $\alpha / \beta$ domain. Shown is the structure of the human $\mathrm{Ku}$ heterodimer bound to DNA based on accession number 1JEY in the protein databank (Walker et al. 2001) and depicted using RasMol. Ku70 is in red, Ku80 in yellow, and DNA in black. The green space-fill residue indicates the position adjacent to where the yku80-135i insertion mutation maps on human Ku80 (Stellwagen et al. 2003), and the blue space-fill indicates the positions of the yku80 8 tel mutations reported by Bertuch and Lundblad (2003), which are defective in telomere end protection, but proficient for DNA repair. quasisymmetric basket-like structure, through which a DNA substrate is threaded and cradled, leaving a minimally exposed end available for repair (Walker et al. 2001). Significant portions of both the Ku70 and Ku80 subunits participate in neither DNA binding nor heterodimerization, and instead form globular domains that have been proposed as potential protein-interaction sites. Alignment of the yeast and human Ku80 proteins shows that most of the amino acids identified in these separation-of-function approaches map to conserved residues, and, therefore, can readily be placed onto the human Ku structure (Fig. 1). Not surprisingly, the mutated residues direct attention to an $\mathrm{N}$-terminal globular domain (termed the $\alpha / \beta$ domain), which is available for interaction with other factors. Stellwagen et al. (2003) have now shown that the telomerase RNA is one such factor in yeast. Interestingly, $\mathrm{Ku}^{\prime}$ s interaction with TLC1 is completely abolished by the yku80-135i mutation, indicating that despite the quasisymmetric appearance of the $\mathrm{N}$-terminal domains of the Ku heterodimer (Walker et al. 2001) and the apparent common ancestry of the Ku70 and Ku80 subunits (Gell and Jackson 1999), distinct interactions with other factors may be delegated to each subunit.

Genetic dissection of the yeast $\mathrm{Ku}$ heterodimer may also instruct us about the in vivo role of the human $\mathrm{Ku}$ protein, as mammalian $\mathrm{Ku}$ is active not only at DSBs but at telomeres as well. In fact, $\mathrm{Ku}$ 's role in telomere end protection is critical to prevent aberrant telomere-telomere fusions (Bailey et al. 1999; Hsu et al. 1999; Samper et al. 2000). Similarly, a role for Ku in mammalian telomere length homeostasis has been reported, although there are conflicting results as to whether it contributes to positive or negative telomere length regulation (d'Adda di Fagagna et al. 2001; Espejel et al. 2002). Translating the information recovered from these yeast separation-of-function analyses should similarly facilitate functional dissection of the multiple activities that $\mathrm{Ku}$ plays in mammalian cells.

\section{References}

Armbruster, B.N., Etheridge, K.T., Broccoli, D., and Counter, C.M. 2003. Putative telomere-recruiting domain in the catalytic subunit of human telomerase. Mol. Cell. Biol. 23: 3237-3246.

Bailey, S.M., Meyne, J., Chen, D.J., Kurimasa, A., Li, G.C., Lehnert, B.E., and Goodwin, E.H. 1999. DNA double-strand break repair proteins are required to cap the ends of mammalian chromosomes. Proc. Nat1. Acad. Sci. 96: 1489914904.

Bertuch, A.A. and Lundblad, V. 2003. The Ku heterodimer performs separable activities at double strand breaks and chromosome termini. Mol. Cell. Biol. (in press).

Booth, C., Griffith, E., Brady, G., and Lydall, D. 2001. Quantitative amplification of single-stranded DNA (QAOS) demonstrates that $c d c 13-1$ mutants generate ssDNA in a telomere to centromere direction. Nucleic Acids Res. 20: 4414-4422.

Boulton, S.J. and Jackson, S.P. 1996. Identification of a Saccharomyces cerevisiae Ku 80 homologue: Roles in DNA double strand break rejoining and in telomeric maintenance. Nucleic Acids Res. 24: 4639-4648.

Chandra, A., Hughes, T.R., Nugent, C.I., and Lundblad, V. 2001. $\mathrm{Cdc} 13$ both positively and negatively regulates telomere replication. Genes \& Dev. 15: 404-414.

d'Adda di Fagagna, F., Hande, M.P., Tong, W.M., Roth, D., Lansdorp, P.M., Wang, Z.Q., and Jackson, S.P. 2001. Effects of DNA nonhomologous end-joining factors on telomere length and chromosomal stability in mammalian cells. Curr. Biol. 11: 1192-1196.

de Lange, T. 2002. Protection of mammalian telomeres. Oncogene 21: 532-540.

Espejel, S., Franco, S., Rodriguez-Perales, S., Bouffler, S.D., Cigudosa, J.C., and Blasco, M.A. 2002. Mammalian Ku86 mediates chromosomal fusions and apoptosis caused by critically short telomeres. EMBO J. 21: 2207-2019.

Evans, S.K. and Lundblad, V. 1999. Est1 and Cdc13 as comediators of telomerase access. Science 286: 117-120.

Friedman, K.L., Heit, J.J., Long, D.M., and Cech, T.R. 2003. Nterminal domain of yeast telomerase reverse transcriptase: Recruitment of Est3p to the telomerase complex. Mol. Biol. Cell 14: 1-13.

Garvik, B., Carson, M., and Hartwell, L. 1995. Single-stranded 
DNA arising at telomeres in $c d c 13$ mutants may constitute a specific signal for the RAD9 checkpoint. Mol. Cell. Biol. 15: 6128-6138.

Gell, D. and Jackson, S.P. 1999. Mapping of protein-protein interactions within the DNA-dependent protein kinase complex. Nucleic Acids Res. 27: 3494-3502.

Gravel, S., Larrivee, M., Labrecque, P., and Wellinger, R.J. 1998. Yeast $\mathrm{Ku}$ as a regulator of chromosomal DNA end structure. Science 280: 741-745.

Hsu, H.L., Gilley, D., Blackburn, E.H., and Chen, D.J. 1999. Ku is associated with the telomere in mammals. Proc. Natl. Acad. Sci. 96: $12454-12458$.

Jackson, S.P. 2002. Sensing and repairing DNA double-strand breaks. Carcinogenesis 23: 687-696.

Kim, M., Xu, L., and Blackburn, E.H. 2003. Catalytically active human telomerase mutants with allele-specific biological properties. Exp. Cell Res. 288: 277-287.

Kolodner, R.D., Putnam, C.D., and Myung, K. 2002. Maintenance of genome stability in Saccharomyces cerevisiae. Science 297: 552-557.

Laroche, T., Martin, S.G., Gotta, M., Gorham, H.C., Pryde, F.E., Louis, E.J., and Gasser, S.M. 1998. Mutation of yeast Ku genes disrupts the subnuclear organization of telomeres. Curr. Biol. 8: 653-656.

Loayza, D. and De Lange, T. 2003. POT1 as a terminal transducer of TRF1 telomere length control. Nature 424: 10131018.

Maringele, L. and Lydall, D. 2002. ExoI-dependent singlestranded DNA at telomeres activates subsets of DNA damage and spindle checkpoint pathways in budding yeast yku70s mutants. Genes \& Dev. 16: 1919-1933.

McEachern, M.J., Krauskopf, A., and Blackburn, E.H. 2000. Telomeres and their control. Annu. Rev. Genet. 34: 331358.

Mishra, K. and Shore, D. 1999. Yeast Ku protein plays a direct role in telomeric silencing and counteracts inhibition by rif proteins. Curr. Biol. 9: 1123-1126.

Myung, K., Datta, A., and Kolodner, R.D. 2001. Suppression of spontaneous chromosomal rearrangements by $S$ phase checkpoint functions in Saccharomyces cerevisiae. Cell 104: 397-408.

Nugent, C.I., Hughes, T.R., Lue, N.F., and Lundblad, V. 1996. Cdc13p: A single-strand telomeric DNA-binding protein with a dual role in yeast telomere maintenance. Science 274: 249-252.

Nugent, C.I., Bosco, G., Ross, L.O., Evans, S.K., Salinger, A.P., Moore, J.K., Haber, J.E., and Lundblad, V. 1998. Telomere maintenance is dependent on activities required for end repair of double-strand breaks. Curr. Biol. 8: 657-660.

Peng, Y., Mian, I.S., and Lue, N.F. 2001. Analysis of telomerase processivity: Mechanistic similarity to HIV-1 reverse transcriptase and role in telomere maintenance. Mol. Cell 7: 1201-1211.

Pennock, E., Buckley, K., and Lundblad, V. 2001. Cdc13 delivers separate complexes to the telomere for end protection and replication. Cell 104: 387-396.

Peterson, S.E., Stellwagen, A.E., Diede, S.J., Singer, M.S., Haimberger, Z.W., Johnson, C.O., Tzoneva, M., and Gottschling, D.E. 2001. The function of a stem-loop in telomerase RNA is linked to the DNA repair protein Ku. Nat. Genet. 27: 64-67.

Polotnianka, R.M., Li, J., and Lustig, A.J. 1998. The yeast Ku heterodimer is essential for protection of the telomere against nucleolytic and recombinational activities. Curr. Biol. 8: 831-834.

Porter, S.E., Greenwell, P.W., Ritchie, K.B., and Petes, T.D. 1996. The DNA-binding protein Hdflp (a putative Ku homo- logue) is required for maintaining normal telomere length in Saccharomyces cerevisiae. Nucleic Acids Res. 24: 582-585. Samper, E., Goytisolo, F.A., Slijepcevic, P., van Buul, P.P., and Blasco, M.A. 2000. Mammalian Ku86 protein prevents telomeric fusions independently of the length of TTAGGG repeats and the G-strand overhang. EMBO Rep. 1: 244-252.

Stellwagen, A.E., Haimberger, Z.W., Veatch, J.R., and Gottschling, D.E. 2003. Ku interacts with telomerase RNA to promote telomere addition at native and broken chromosome ends. Genes \& Dev. (this issue).

Taccioli, G.E., Gottlieb, T.M., Blunt, T., Priestley, A., Demengeot, J., Mizuta, R., Lehmann, A.R., Alt, F.W., Jackson, S.P., and Jeggo, P.A. 1994. Ku80: Product of the XRCC5 gene and its role in DNA repair and $\mathrm{V}(\mathrm{D}) \mathrm{J}$ recombination. Science 265: 1442-1445.

van Steensel, B., Smogorzewska, A., and de Lange, T. 1998. TRF2 protects human telomeres from end-to-end fusions. Cell 92: 401-413.

Walker, J.R., Corpina, R.A., and Goldberg, J. 2001. Structure of the $\mathrm{Ku}$ heterodimer bound to DNA and its implications for double-strand break repair. Nature 412: 607-614. 


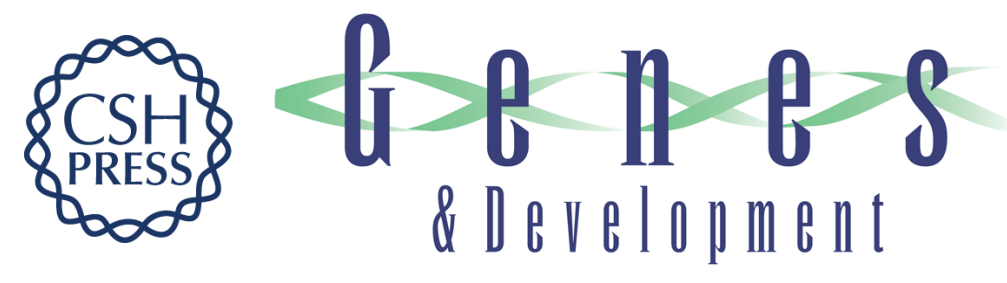

\section{Which end: dissecting Ku's function at telomeres and double-strand breaks}

Alison A. Bertuch and Victoria Lundblad

Genes Dev. 2003, 17:

Access the most recent version at doi:10.1101/gad.1146603

References This article cites 32 articles, 13 of which can be accessed free at: http://genesdev.cshlp.org/content/17/19/2347.full.html\#ref-list-1

License

Email Alerting

Receive free email alerts when new articles cite this article - sign up in the box at the top Service right corner of the article or click here.

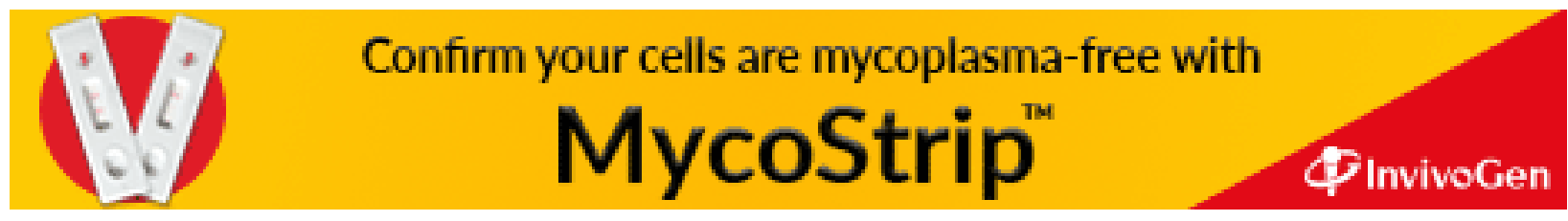

